\title{
Breast Milk Hormones and Their Protective Effect on Obesity
}

\author{
Francesco Savino, Stefania A. Liguori, Maria F. Fissore, and Roberto Oggero \\ Department of Pediatrics, Regina Margherita Children's Hospital, University of Turin, 10126 Turin, Italy \\ Correspondence should be addressed to Francesco Savino, francesco.savino@unito.it
}

Received 8 May 2009; Accepted 27 September 2009

Recommended by Jesus Argente

Data accumulated over recent years have significantly advanced our understanding of growth factors, cytokines, and hormones in breast milk. Here we deal with leptin, adiponectin, IGF-I, ghrelin, and the more recently discovered hormones, obestatin, and resistin, which are present in breast milk and involved in food intake regulation and energy balance. Little is known about these compounds in infant milk formulas. Nutrition in infancy has been implicated in the long-term tendency to obesity, and a longer duration of breastfeeding appears to protect against its development. Diet-related differences in serum leptin and ghrelin values in infancy might explain anthropometric differences and differences in dietary habits between breast-fed and formula-fed infants also later in life. However, there are still gaps in our understanding of how hormones present in breast milk affect children. Here we examine the data related to hormones contained in mother's milk and their potential protective effect on subsequent obesity.

Copyright (C) 2009 Francesco Savino et al. This is an open access article distributed under the Creative Commons Attribution License, which permits unrestricted use, distribution, and reproduction in any medium, provided the original work is properly cited.

\section{Introduction}

Studies on the physiology of breastfeeding revealed the presence of the two adipokines, leptin [1] and adiponectin [2], hormones, such as IGF-I [3], ghrelin [4], and more recently obestatin [5] and resistin [6] in mother's milk (Table 1). Human milk is a complex biological fluid: leptin and ghrelin are synthesized and secreted into breast milk by the mammary gland and pass from serum into milk. The origin of adiponectin, obestatin, and resistin remains to be established. Leptin and ghrelin have a positive effect on the early control of satiety in infants and could influence the programming of energy balance regulation in childhood and adulthood thereby protecting against later obesity [7]. It is noteworthy that childhood obesity is associated with an increased risk of adult metabolic syndrome [8].

Here, we review data related to hormones contained in mother's milk and their potential protective effect on subsequent obesity.

1.1. Leptin. Leptin is an adipocyte-derived hormone discovered in 1994 [9]. It reduces appetite and increases energy expenditure by acting on the arcuate nucleus in the hypothalamus through its receptor (Ob-R) [10]. Circulating leptin levels correlate with fat mass in adults and children [11].
Leptin is detectable in cord blood from the second trimester of intrauterine life and correlates with adiposity at birth [12]. Interestingly, serum leptin concentration correlates with body mass index (BMI) in infants [13].

In obese subjects, endogenous leptin, even at high circulating levels, fails to exert its normal effects, and administration of exogenous leptin does not significantly reduce adiposity. This condition, known as "leptin resistance", could be due to reduced transport of leptin into the brain and reduced expression of leptin receptor in the arcuate nucleus or an increased concentration of SOCS3, which suppresses leptin signaling by inhibiting leptin-induced STAT activation [14].

Leptin has been implicated in the neonatal development of the hypothalamic pathways involved in the central regulation of energy balance and appetite [15]. Studies conducted in mice have shown that by acting on the brain during a critical neonatal period that coincides with a naturally occurring leptin surge, leptin promotes the formation of neural circuits that control food intake and adiposity later in life [16].

In humans, cord blood leptin concentration has been observed to be inversely related to rates of intrauterine growth, suggesting a possible role of leptin in promoting fetus growth: small-for-gestational age (SGA) neonates have 
TABLE 1: Breast milk hormones.

\begin{tabular}{|c|c|c|c|c|c|c|c|}
\hline Hormone & $\begin{array}{c}\text { Year of } \\
\text { discovery }\end{array}$ & Receptor & $\begin{array}{l}\text { Detection of } \\
\text { receptor in } \\
\text { intestine }\end{array}$ & Main functions & $\begin{array}{l}\text { Year of } \\
\text { discovery in } \\
\text { breast milk }\end{array}$ & $\begin{array}{l}\text { Method of } \\
\text { detection in } \\
\text { breast milk }\end{array}$ & $\begin{array}{c}\text { Detection in } \\
\text { umbilical } \\
\text { cord blood }\end{array}$ \\
\hline Leptin & 1994 & Ob-receptor & In humans [17] & Anorexigenic effect & 1997 & $\begin{array}{l}\text { RIA }[1,18] \text {, } \\
\text { ELISA [16] }\end{array}$ & {$[12,19,20]$} \\
\hline Adiponectin & 1995 & $\begin{array}{l}\text { Adipo-R1 } \\
\text { Adipo-R2 }\end{array}$ & In humans [21] & $\begin{array}{l}\text { Improvement of } \\
\text { insulin sensitivity, } \\
\text { increase in fatty } \\
\text { acid metabolism, } \\
\text { anti-inflammatory } \\
\text { and } \\
\text { anti-atherogenic } \\
\text { properties }\end{array}$ & 2006 & $\begin{array}{c}\text { RIA [2], } \\
\text { ELISA [22] }\end{array}$ & {$[20]$} \\
\hline Ghrelin & 1999 & $\begin{array}{l}\text { Growth hormone } \\
\text { secretagogue } \\
\text { receptor -1a }\end{array}$ & In humans [23] & $\begin{array}{l}\text { Orexigenic action; } \\
\text { stimulation of GH } \\
\text { secretion; } \\
\text { stimulation of acid } \\
\text { gastric secretion } \\
\text { and motility }\end{array}$ & 2006 & RIA $[4,24]$ & {$[25]$} \\
\hline IGF-I & 1950 & $\begin{array}{l}\text { IR IGF-IR IGF-IIR } \\
\text { Insulin } \\
\text { receptor-related } \\
\text { receptor IR-IGF-IR } \\
\text { hybrid receptor }\end{array}$ & In humans [26] & $\begin{array}{l}\text { Primary mediator } \\
\text { of growth } \\
\text { hormone effects; } \\
\text { role in the } \\
\text { regulation of } \\
\text { postnatal human } \\
\text { growth from late } \\
\text { infancy onward }\end{array}$ & 1984 & RIA [3] & $\begin{array}{l}\text { Ibáñez L } \\
\text { et al., 2008; } \\
\text { Lagiou P } \\
\text { et al., } 2009\end{array}$ \\
\hline Resistin & 2001 & Unknown & Unknown & $\begin{array}{l}\text { Regulation of } \\
\text { insulin sensitivity }\end{array}$ & 2008 & ELISA [6] & {$[27]$} \\
\hline Obestatin & 2005 & GPR39 & In mice [28] & $\begin{array}{l}\text { Anorexigenic } \\
\text { effect? }\end{array}$ & 2008 & RIA [5] & Unknown? \\
\hline
\end{tabular}

lower leptin levels at birth than appropriate-for-gestational age (AGA) infants, and large-for-gestational age (LGA) neonates have higher leptin levels than other infants [19].

Cord blood leptin seems to be a predictor of weight gain also in later life; in fact lower cord blood leptin levels have been observed to be associated with smaller size at birth but more pronounced weight gain in the first 6 months of life and higher BMI at 3 years of age [20].

Leptin is present in human milk [1]; it is produced and secreted by mammary epithelial cells in milk fat globules [29]. Moreover, secretory epithelial cells may transfer leptin from the blood to milk [30]. Leptin concentration was found to be higher in whole than in skimmed samples of human milk [18], probably because a portion of leptin could be associated with the milk fat droplet or fat-associated proteins. Leptin concentration was also higher in colostrum than in transitional milk (4-5 days postpartum milk) [31]. Leptin receptors have been identified in gastric epithelial cells and in the absorptive cells of mouse and human small intestine [17], which suggests that leptin could pass from milk to infant blood and might play a role in the shortterm regulation of feeding. This could occur during early lactation. In fact, when neonatal rats were orally supplied with leptin, the hormone was directly taken up by the stomach thereby resulting in an increase in leptin levels in the stomach and serum [32]. When these rats were fed a chow or a high-fat diet from weaning, those that received physiological doses of oral leptin during the suckling period had a lower body weight and less adiposity in adulthood; they also had greater insulin sensitivity and showed a lower preference for fat-rich food than their controls [33]. Consequently, breast milk leptin could play a role in the short-term control of food intake in neonates by acting as a satiety signal and could also exert a long-term effect on energy balance and body weight regulation $[34,35]$. Leptin concentrations in breast milk were found to correlate positively with maternal circulating leptin levels, maternal BMI, and the mother's adiposity [36]. A positive correlation has also been reported between breast milk leptin levels and infant plasma leptin [37]. We observed higher serum leptin concentrations in breast-fed infants than in formulafed babies in the first months of life [38] and a positive correlation between serum leptin concentration in breastfed infants and maternal BMI [39]. The presence of leptin in the breast milk of nonobese mothers at 1 month of lactation was found to be negatively correlated with infant BMI at 18 and 24 months of age [40]. Further studies are required to better understand if leptin in human milk could play a role in differences in adiposity later in life according to the type of early feeding; in the first months of life, the relation between 
leptin and infant body composition may be present but still remains an undefined link [12].

Using radioimmunoassay, Lage et al. reported variable leptin concentrations in commercial bovine milk and in infant formulas [41]. However, according to O'Connor et al., radioimmunoassay is not appropriate for the detection of leptin in infant formulas because supplemented iron, emulsifiers and other additives contained in formulas could confound the assay [42]. Therefore, further research is required to determine whether leptin is present in milk formula.

1.2. Adiponectin. Adiponectin is the most abundant adiposespecific protein, and its multiple functions have only recently started to emerge [43]. It was discovered in breast milk in 2006 by Martin et al. [2] and Bronsky et al [22]. Martin et al. recently reported that adiponectin levels in human milk decreased with the duration of lactation [2]. Adiponectin circulates in very high concentrations in human serum and its levels are inversely related to the degree of adiposity and positively associated with insulin sensitivity. In fact, plasma adiponectin concentrations are decreased in individuals with obesity and type 2 diabetes [44].

Cord blood adiponectin levels have been observed to be directly associated with birth weight for gestational age, inversely associated with weight gain in the first 6 months of life, and to predict an increase in adiposity in 3 years oldchildren [20].

Circulating adiponectin levels correlate negatively with the degree of adiposity also in children aged between 5 and 10 years [45]. In contrast, in full-term infants during the first few days of life, serum and plasma adiponectin levels correlate positively with birth weight and length, neonatal adiposity, and circulating levels of leptin [46]. In preterm infants, serum adiponectin levels are lower than in full-term infants, correlate positively with body weight, and increase with postnatal age, which suggests a metabolic adaptation to premature extrauterine life [47]. Given the biological properties of adiponectin, its presence in breast milk, and the expression of adiponectin receptor 1 in the small intestine of neonatal mice [48] and of adiponectin receptor 1 and 2 in human colon epithelium [21], not only adiponectin produced by adipose tissue but also milk adiponectin may affect infant growth and development. Weyermann et al. found that higher levels of adiponectin in breast milk were associated with overweight at two years of age in infants who were breast-fed for at least 6 months [49]. Further research is needed to evaluate whether exposure to adipokine in infancy determines later weight status [50].

Bronsky et al. recently detected in human breast milk also fatty acid binding proteins, which are produced by adipose tissue and are related to lipid metabolism [22].

1.3. Resistin. Resistin was discovered in 2001 as a cytokine secreted by adipocytes [51]. It was recently identified in human milk by Ilcol et al. [6]. They found that resistin levels decreased during lactation. Moreover, resistin concentrations in both milk and serum of breastfeeding mothers correlated positively with hormone status (estradiol, progesterone, prolactin, thyroxine, triiodothyronine, cortisol, and leptin levels) and with concentrations of the inflammatory parameter C-reactive protein. Lastly, they found that resistin concentrations were higher in the serum of breast-fed infants than in either breast milk or their mother's serum [3]. Resistin was associated with insulin resistance in obese mice; however homology between mouse and human resistin is only $64 \%$. Resistin has not been associated with insulin resistance or obesity in humans, and the determination of resistin as a marker of insulin resistance in children is not recommended [52]. In the perinatal period, it seems that resistin is not directly involved in the regulation of insulin sensitivity or adipogenesis [53]. Circulating resistin levels were found to be elevated in both genetic (ob/ob and $\mathrm{db} / \mathrm{bd}$ ) and diet-induced mouse obesity and insulinresistance models [8]. The role of resistin in fetal and infantile growth remains to be established. However, in this context, it is known that umbilical serum resistin levels correlate positively with maternal serum resistin levels and negatively with neonatal birth weight [27]. This finding suggests that resistin could have a role in controlling fetal growth and, like the other breast milk hormones, could be involved in appetite regulation and in the metabolic development of infants.

1.4. Ghrelin. Ghrelin is a 28 -amino-acid peptide produced primarily in the stomach and so called for its property of stimulating GH secretion in humans [54]. Significant ghrelin concentrations are present in human cord blood [25] and ghrelin is a component of breast milk; it comes from plasma [4] but also it is produced and secreted by the breast, considering that ghrelin levels in breast milk are higher than those found in plasma itself [24].

A portion of serum ghrelin possesses a fatty acid modification, an $n$-octanoylation, at the Ser 3 residue. This acylated form, also known as "active ghrelin," exerts the same biological effects as the hormone. Acylated ghrelin has also been reported in breast milk; its concentrations increase during lactation and are significantly related with serum ghrelin concentrations in breast-fed infants [55].

We identified a direct correlation between the circulating level of ghrelin and age, weight, and length in infants in the first months of life and a negative correlation between circulating ghrelin levels and weight gain only in infants who have been breast-fed for at least four months, but not in them who have been formula fed [56]. We also observed higher ghrelin values in formula-fed infants [57] and, more recently, a positive correlation between circulating ghrelin levels and fasting time in the first 6 months of life in infants fed exclusively with formula [58].

Ghrelin stimulates food intake in rats and humans [59] by acting primarily on the arcuate nucleus of the hypothalamus. Ghrelin also exerts adipogenic activity, and is involved in the long-term regulation of body weight [60]. Administration of ghrelin induced body weight gain and adiposity in rodents by stimulating food intake and reducing fat utilization and energy expenditure [61]. Considering that ghrelin is involved both in short-term regulation of food intake, by stimulating appetite, and in long-term 
body-weight regulation, by inducing adiposity, the presence of this hormone in breast milk could be one of the factors through which breast-feeding may influence infant feeding behavior and body composition later in life.

1.5. Obestatin. Obestatin, a 23-amino-acid peptide derived from the ghrelin peptide precursor preproghrelin and produced by the human stomach, small intestine [62], and salivary glands [63], was identified in breast milk by Aydin and colleagues in 2008 [4]. They evaluated obestatin levels in serum and milk from 31 lactating women on days 2 (colostrum) and 25 (mature milk) after delivery and found higher hormone levels in milk than in blood: obestatin levels in colostrum and mature milk were more than twice the corresponding blood levels. It is not clear if obestatin comes from the blood or breast but it may drain through the mammary glands into the milk. The effect of this hormone is not well known. Some authors report that it reduces food intake, body weight gain, and gastric emptying and suppresses intestinal motility [4]. Obestatin is involved in inhibiting thirst and anxiety, improving memory, regulating sleep, inducing cell proliferation, and increasing exocrine pancreatic secretion $[64,65]$. Plasma obestatin levels are increased in subjects with anorexia nervosa, in whom obestatin seemed to be a marker of acute and chronic changes in nutritional state [66]. The relationship between obestatin and infant metabolic development merits further study.

1.6. Insulin-Like Growth Factor-I. IGF-I, a 70-amino acid single chain polypeptide, is a member of a superfamily of related insulin-like hormones, and it acts as the primary mediator of growth hormone $(\mathrm{GH})$ effects. The $75 \%$ of circulating IGF-I is produced by the liver, and postnatal hepatic production is regulated by pituitary $\mathrm{GH}$ as well as nutritional factors; it plays a role in the regulation of postnatal human growth from late infancy onward [67].

IGF-I acts through different receptors, that are the insulin receptor (IR), IGF-IR, IGF-IIR, and several atypical receptors, including the insulin receptor-related receptor and the IR-IGF-IR hybrid receptor (composed of an IR hemireceptor linked to an IGF-IR hemi-receptor) [68]. A family of six high-affinity IGF-binding proteins (IGFBP-1 through IGFBP-6) coordinate and regulate the biological activity of IGF.

IGF-I levels decrease with sustained fasting and poor nutritional status but are unaffected by recent food intake.

IGF-I plays a key role in both embryonic and postnatal growth. Evidences from literature show a correlation between IGF-I levels in cord blood and birth weight [69]; in particular, it has been demonstrated that children with intrauterine growth retardation showed lower concentrations than normal children [70].

Further, IGF-I levels in humans correlate with body size; Klagsburn was the first to show that human milk contained growth factors that stimulated the growth of cells in culture [71]. Baxter et al. demonstrated the presence of IGF-I in human milk [3]; its levels are several-fold higher in colostrum than in mature milk and they decrease in the first few days of lactation.
More recently, IGF-binding proteins (IGFBPs) have been identified in human milk of term and preterm infants [72].

Infants fed with formula milk during the first months of life showed higher IGF-I levels than BF ones [57]. A recent study showed a positive correlation between IGF-I values and $\mathrm{Z}$ score for weight, BMI, tricipital skin-fold thickness, and age in healthy infants in the first 5 months of life, sustaining a possible programming of IGF-I axis during infancy [73].

\section{Breastfeeding and Obesity}

Obesity is a relevant public health problem in both industrialized and developing countries [74], especially because of obesity-related chronic diseases. The rise in obesity has been particularly steep in children. Overweight and obesity result primarily from excess energy intake versus energy expenditure [75]. The interaction between genetic factors that determine susceptibility to weight gain and lifestyle [76] (increased consumption of energy-dense foods and reduced physical activity) is a key factor in the development of obesity. However, recent research suggests that long-term health could be determined during fetal and early postnatal life. The relationship between low birth weight, catch-up growth during the first years of life, and the later occurrence of obesity, insulin resistance, cardiovascular diseases, hyperlipidemia, and type 2 diabetes has been amply documented [77, 78]. Experimental models and epidemiological studies suggest that early nutrition is a key factor for the development of obesity later in life, thereby supporting the concept of "nutritional programming" [79]. In particular, breastfeeding could play a key role in the programming process during early life, but it is still difficult to draw definitive conclusions about the causal relationship between breastfeeding and such long-term health benefits as prevention of obesity. A casecontrol study by Kramer was one of the first studies to suggest that breastfeeding exerts a protective effect on later obesity [80]. Because it is not ethical to perform randomized experimental studies involving breastfeeding, the data available come from observational studies, and confounding variables remain an issue. Observational studies have confirmed an association between breastfeeding and reduced risk of subsequent obesity, as shown in recent systematic reviews $[81,82]$. In particular, Harder et al. reported that prolonged breastfeeding had a beneficial effect on the risk of overweight in later life [83]. Armstrong et al. studied a large cohort study of Scottish children and found that breastfeeding was associated with a reduction in childhood obesity risk [84]. But, how does breastfeeding exert these beneficial effects? The potential benefits of breastfeeding on long-term obesity and cardiovascular disease may be due to slower growth in breast-fed infants compared to formula-fed infants [85]. The potential mechanisms by which breastfeeding protects against rapid weight gain and consequently against later obesity are the same as those that influence nutritional behavior and those related to human milk composition. From a behavioral viewpoint, because breast-fed babies can self-control the amount of milk they consume, they may learn to self-regulate their energy intake better than formulafed infants [86], although it is not clear if this could influence 
nutritional behavior later in life. Moreover, parents who choose to breast feed their babies generally have a healthier lifestyle, and this tends to influence the lifestyle (including diet and exercise) of offspring. Differences in energy and protein content between human milk and infant formula might play a role in programming obesity risk: most infant formulas have a slightly higher energy density and a higher protein content than human milk [87]. A high protein intake in infancy has been suggested to enhance the secretion of insulin and IGF-I with a consequent stimulation of cell proliferation, which promotes an accelerated growth and an increased adipose tissue [88]. Epidemiologic studies shown that high protein intake in early childhood was predictive of an early occurrence of adiposity rebound [89]. In a recent randomized clinical trial an association between a higher protein content of infant formula and higher weight in the first two years of life has been reported [90].

Regarding the issue of human milk composition compared to formula milk, breast milk contains bioactive nutrients that are not present in formula milk [91].

It is known that human milk contains numerous growth modulators, such as epidermal growth factor (EGF) [92], insulin [93], and IGFs, which can stimulate gastrointestinal mucosal proliferation and facilitate maturation and closure of the neonatal gastrointestinal tract [94]. Receptors for these growth factors have been found throughout the gastrointestinal tract and these factors are relatively resistant to proteolysis and remain stable in the gastrointestinal tract [95]. Thus, many factors acting in concert affect gut maturation, leading gastrointestinal tract to change from an organ of relatively high intestinal permeability to one of selective permeability.

The recent identification in breast milk of adipokines and other hormones involved in energy balance regulation suggests that breast milk may uniquely modulate neuroendocrine pathways involved in the regulation of body weight. For leptin [17], adiponectin [48], IGF-I [26], obestatin [28], and ghrelin [23] gastrointestinal receptors have been found, even though it is still not well defined if these hormones are resistant to proteolysis and if these receptors can mediate their absorption and action.

The presence of growth factors, enzymes, hormones, and cytokines gives to breast milk unique properties useful for the maturating neonatal gut and for the metabolic development of infants.

\section{Concluding Remarks}

It is likely that the next few years will see the emergence of the mechanisms by which early-life programming determines the set-point of energy balance. One mechanism by which breast-feeding may protect against the development of childhood obesity is through the activity of components of breast milk such as hormones involved in appetite and energy balance that we describe in this review. Differences in growth pattern and body composition between breastfed and formula-fed infants might be due to a different endocrine response to feeding or to bioactive substances present in breast milk that could influence the infant's response to energy intake and metabolism [96]. However, we are still far short of understanding the effects on children of hormones present in breast milk. Longitudinal investigations will shed light on the new hormones discovered in mother's milk and their potential protective effect on subsequent obesity and metabolic-related disorders.

\section{References}

[1] X. Casabiell, V. Piñeiro, M. A. Tomé, R. Peinó, C. Dieguez, and F. F. Casanueva, "Presence of leptin in colostrum and/or breast milk from lactating mothers: a potential role in the regulation of neonatal food intake," The Journal of Clinical Endocrinology \& Metabolism, vol. 82, no. 12, pp. 4270-4273, 1997.

[2] L. J. Martin, J. G. Woo, S. R. Geraghty, et al., "Adiponectin is present in human milk and is associated with maternal factors," The American Journal of Clinical Nutrition, vol. 83, no. 5, pp. 1106-1111, 2006.

[3] R. C. Baxter, Z. Zaltsman, and J. R. Turtle, "Immunoreactive somatomedin-C/insulin-like growth factor I and its binding protein in human milk," The Journal of Clinical Endocrinology \& Metabolism, vol. 58, no. 6, pp. 955-959, 1984.

[4] S. Aydin, S. Aydin, Y. Ozkan, and S. Kumru, "Ghrelin is present in human colostrum, transitional and mature milk," Peptides, vol. 27, no. 4, pp. 878-882, 2006.

[5] S. Aydin, Y. Ozkan, F. Erman, et al., "Presence of obestatin in breast milk: relationship among obestatin, ghrelin, and leptin in lactating women," Nutrition, vol. 24, no. 7-8, pp. 689-693, 2008.

[6] Y. O. Ilcol, Z. B. Hizli, and E. Eroz, "Resistin is present in human breast milk and it correlates with maternal hormonal status and serum level of C-reactive protein," Clinical Chemistry and Laboratory Medicine, vol. 46, no. 1, pp. 118-124, 2008.

[7] F. Savino and S. A. Liguori, "Update on breast milk hormones: leptin, ghrelin and adiponectin," Clinical Nutrition, vol. 27, no. 1, pp. 42-47, 2008.

[8] S. S. Sun, R. Liang, T. T. Huang, et al., "Childhood obesity predicts adult metabolic syndrome: the fels longitudinal study," Journal of Pediatrics, vol. 152, no. 2, pp. 191-200, 2008.

[9] Y. Zhang, R. Proenca, M. Maffei, M. Barone, L. Leopold, and J. M. Friedman, "Positional cloning of the mouse obese gene and its human homologue," Nature, vol. 372, no. 6505, pp. 425432, 1994.

[10] C. de Graaf, W. A. M. Bloom, P. A. M. Smeets, A. Stafleu, and H. F. J. Hendriks, "Biomarkers of satiation and satiety," The American Journal of Clinical Nutrition, vol. 79, no. 6, pp. 946961, 2004.

[11] T. R. Nagy, B. A. Gower, C. A. Trowbridge, C. Dezenberg, R. M. Shewchuk, and M. I. Goran, "Effects of gender, ethnicity, body composition, and fat distribution on serum leptin concentrations in children," The Journal of Clinical Endocrinology \& Metabolism, vol. 82, no. 7, pp. 2148-2152, 1997.

[12] P.-J. Tsai, C.-H. Yu, S.-P. Hsu, et al., "Cord plasma concentrations of adiponectin and leptin in healthy term neonates: positive correlation with birthweight and neonatal adiposity," Clinical Endocrinology, vol. 61, no. 1, pp. 88-93, 2004.

[13] F. Savino, S. A. Liguori, M. F. Fissore, et al., "Looking for a relation between serum leptin concentration and body composition parameters in healthy term infants in the first 6 months of life," The Journal of Pediatric Gastroenterology and Nutrition, vol. 46, no. 3, pp. 348-351, 2008. 
[14] M. G. Myers, M. A. Cowley, and H. Münzberg, "Mechanisms of leptin action and leptin resistance," Annual Review of Physiology, vol. 70, pp. 537-556, 2008.

[15] S. C. Woods and D. A. D'Alessio, "Central control of body weight and appetite," The Journal of Clinical Endocrinology \& Metabolism, vol. 93, no. 11, supplement 1, pp. s37-s50, 2008.

[16] S. G. Bouret and R. B. Simerly, "Developmental programming of hypothalamic feeding circuits," Clinical Genetics, vol. 70, no. 4, pp. 295-301, 2006.

[17] J. Barrenetxe, A. C. Villaro, L. Guembe, et al., "Distribution of the long leptin receptor isoform in brush border, basolateral membrane, and cytoplasm of enterocytes," Gut, vol. 50, no. 6, pp. 797-802, 2002.

[18] K. L. Houseknecht, M. K. McGuire, C. P. Portocarrero, M. A. McGuire, and K. Beerman, "Leptin is present in human milk and is related to maternal plasma leptin concentration and adiposity," Biochemical and Biophysical Research Communications, vol. 240, no. 3, pp. 742-747, 1997.

[19] H. A. Koistinen, V. A. Koivisto, S. Andersson, et al., "Leptin concentration in cord blood correlates with intrauterine growth," The Journal of Clinical Endocrinology \& Metabolism, vol. 82, no. 10, pp. 3328-3330, 1997.

[20] C. S. Mantzoros, S. L. Rifas-Shiman, C. J. Williams, J. L. Fargnoli, T. Kelesidis, and M. W. Gillman, "Cord blood leptin and adiponectin as predictors of adiposity in children at 3 years of age: a prospective cohort study," Pediatrics, vol. 123, no. 2, pp. 682-689, 2009.

[21] K. Yoneda, A. Tomimoto, H. Endo, et al., "Expression of adiponectin receptors, AdipoR1 and AdipoR2, in normal colon epithelium and colon cancer tissue," Oncology Reports, vol. 20, no. 3, pp. 479-483, 2008.

[22] J. Bronsky, M. Karpisek, E. Bronska, et al., "Adiponectin, adipocyte fatty acid binding protein, and epidermal fatty acid binding protein: proteins newly identified in human breast milk," Clinical Chemistry, vol. 52, no. 9, pp. 1763-1770, 2006.

[23] E. Takeshita, B. Matsuura, M. Dong, L. J. Miller, H. Matsui, and M. Onji, "Molecular characterization and distribution of motilin family receptors in the human gastrointestinal tract," Journal of Gastroenterology, vol. 41, no. 3, pp. 223-230, 2006.

[24] J. Kierson, D. Dimatteo, R. G. Locke, A. B. MacKley, and M. L. Spear, "Ghrelin and cholecystokinin in term and preterm human breast milk," Acta Pædiatrica, vol. 95, no. 8, pp. 991995, 2006.

[25] J.-P. Chanoine, L. P. Yeung, A. C. Wong, and C. L. Birmingham, "Immunoreactive ghrelin in human cord blood: relation to anthropometry, leptin, and growth hormone," The Journal of Pediatric Gastroenterology and Nutrition, vol. 35, no. 3, pp. 282-286, 2002.

[26] S. Freier, M. Eran, C. Reinus, et al., "Relative expression and localization of the insulin-like growth factor system components in the fetal, child and adult intestine," The Journal of Pediatric Gastroenterology and Nutrition, vol. 40, no. 2, pp. 202-209, 2005.

[27] G. J. Cho, S. W. Yoo, S. C. Hong, et al., "Correlations between umbilical and maternal serum resistin levels and neonatal birth weight," Acta Obstetricia et Gynecologica Scandinavica, vol. 85, no. 9, pp. 1051-1056, 2006.

[28] J. V. Zhang, H. Jahr, C.-W. Luo, et al., "Obestatin induction of early-response gene expression in gastrointestinal and adipose tissues and the mediatory role of $\mathrm{G}$ protein-coupled receptor, GPR39," Molecular Endocrinology, vol. 22, no. 6, pp. 1464 $1475,2008$.
[29] S. M. Smith-Kirwin, D. M. O'Connor, J. de Johnston, E. D. Lancey, S. G. Hassink, and V. L. Funanage, "Leptin expression in human mammary epithelial cells and breast milk," The Journal of Clinical Endocrinology \& Metabolism, vol. 83, no. 5, pp. 1810-1813, 1998.

[30] M. Bonnet, C. Delavaud, K. Laud, et al., "Mammary leptin synthesis, milk leptin and their putative physiological roles," Reproduction Nutrition Development, vol. 42, no. 5, pp. 399413, 2002.

[31] J. Bielicki, R. Huch, and U. von Mandach, "Time-course of leptin levels in term and preterm human milk," European Journal of Endocrinology, vol. 151, no. 2, pp. 271-276, 2004.

[32] J. Sánchez, P. Oliver, O. Miralles, E. Ceresi, C. Picó, and A. Palou, "Leptin orally supplied to neonate rats is directly uptaken by the immature stomach and may regulate shortterm feeding," Endocrinology, vol. 146, no. 6, pp. 2575-2582, 2005.

[33] J. Sánchez, T. Priego, M. Palou, A. Tobaruela, A. Palou, and C. Picó, "Oral supplementation with physiological doses of leptin during lactation in rats improves insulin sensitivity and affects food preferences later in life," Endocrinology, vol. 149, no. 2, pp. 733-740, 2008.

[34] C. J. Stocker and M. A. Cawthorne, "The influence of leptin on early life programming of obesity," Trends in Biotechnology, vol. 26, no. 10, pp. 545-551, 2008.

[35] A. Palou and C. Picó, "Leptin intake during lactation prevents obesity and affects food intake and food preferences in later life," Appetite, vol. 52, no. 1, pp. 249-252, 2009.

[36] Y. O. Ilcol, Z. B. Hizli, and T. Ozkan, "Leptin concentration in breast milk human and its relationship to duration of lactation and hormonal status," International Breastfeeding Journal, vol. 17, pp. 1-21, 2006.

[37] B. Ucar, B. Kirel, O. Bör, et al., "Breast milk leptin concentrations in initial and terminal milk samples: relationships to maternal and infant plasma leptin concentrations, adiposity, serum glucose, insulin, lipid and lipoprotein levels," The Journal of Pediatric Endocrinology \& Metabolism, vol. 13, no. 2, pp. 149-156, 2000.

[38] F. Savino, S. A. Liguori, M. M. Lupica, M. F. Fissore, and R. Oggero, "Leptin levels in breast-fed infants," Clinical Endocrinology, vol. 64, pp. 596-598, 2006.

[39] F. Savino, S. A. Liguori, R. Oggero, L. Silvestro, and R. Miniero, "Maternal BMI and serum leptin concentration of infants in the first year of life," Acta Pædiatrica, vol. 95, no. 4, pp. 414418, 2006.

[40] O. Miralles, J. Sánchez, A. Palou, and C. Picó, "A physiological role of breast milk leptin in body weight control in developing infants," Obesity, vol. 14, no. 8, pp. 1371-1377, 2006.

[41] M. Lage, R. Baldelli, J. P. Camina, et al., "Presence of bovine leptin in edible commercial milk and infant formula," Journal of Endocrinological Investigation, vol. 25, no. 8, pp. 670-674, 2002.

[42] D. O'Connor, V. Funanage, R. Locke, M. Spear, and K. Leef, "Leptin is not present in infant formulas," Journal of Endocrinological Investigation, vol. 26, no. 5, p. 490, 2003.

[43] P. E. Scherer, S. Williams, M. Fogliano, G. Baldini, and H. F. Lodish, "A novel serum protein similar to C1q, produced exclusively in adipocytes," The Journal of Biological Chemistry, vol. 270, no. 45, pp. 26746-26749, 1995.

[44] C. Weyer, T. Funahashi, S. Tanaka, et al., "Hypoadiponectinemia in obesity and type 2 diabetes: close association with insulin resistance and hyperinsulinemia," The Journal of Clinical Endocrinology \& Metabolism, vol. 86, no. 5, pp. 19301935, 2001. 
[45] N. Stefan, J. C. Bunt, A. D. Salbe, T. Funahashi, Y. Matsuzawa, and P. A. Tataranni, "Plasma adiponectin concentrations in children: relationships with obesity and insulinemia," The Journal of Clinical Endocrinology \& Metabolism, vol. 87, no. 10, pp. 4652-4656, 2002.

[46] I. Inami, T. Okada, H. Fujita, et al., "Impact of serum adiponectin concentration on birth size and early postnatal growth," Pediatric Research, vol. 61, no. 5, part 1, pp. 604-606, 2007.

[47] T. Siahanidou, H. Mandyla, G.-P. Papassotiriou, I. Papassotiriou, and G. Chrousos, "Circulating levels of adiponectin in preterm infants," Archives of Disease in Childhood, vol. 92, no. 4, pp. F286-F290, 2007.

[48] Y. Zhou, X. Sun, L. Jin, T. Stringfield, L. Lin, and Y. Chen, "Expression profiles of adiponectin receptors in mouse embryos," Gene Expression Patterns, vol. 5, no. 5, pp. 711-715, 2005.

[49] M. Weyermann, H. Brenner, and D. Rothenbacher, "Adipokines in human milk and risk of overweight in early childhood: a prospective cohort study," Epidemiology, vol. 18, no. 6, pp. 722-729, 2007.

[50] M. W. Gillman and C. S. Mantzoros, "Breast-feeding, adipokines, and childhood obesity," Epidemiology, vol. 18, no. 6, pp. 730-732, 2007.

[51] C. M. Steppan, S. T. Bailey, S. Bhat, et al., "The hormone resistin links obesity to diabetes," Nature, vol. 409, no. 6818, pp. 307-312, 2001.

[52] F. Eyzaguirre and V. Mericq, "Insulin resistance markers in children," Hormone Research, vol. 71, no. 2, pp. 65-74, 2009.

[53] D. D. Briana, M. Boutsikou, S. Baka, et al., "Perinatal changes of plasma resistin concentrations in pregnancies with normal and restricted fetal growth," Neonatology, vol. 93, no. 3, pp. 153-157, 2008.

[54] M. Kojima and K. Kangawa, "Ghrelin: structure and function," Physiological Reviews, vol. 85, no. 2, pp. 495-522, 2005.

[55] Y. O. Ilcol and B. Hizli, "Active and total ghrelin concentrations increase in breast milk during lactation," Acta Pædiatrica, vol. 96, no. 11, pp. 1632-1639, 2007.

[56] F. Savino, S. A. Liguori, M. F. Fissore, R. Oggero, L. Silvestro, and R. Miniero, "Serum ghrelin concentration and weight gain in healthy term infants in the first year of life," The Journal of Pediatric Gastroenterology and Nutrition, vol. 41, no. 5, pp. 653-659, 2005.

[57] F. Savino, M. F. Fissore, E. C. Grassino, G. E. Nanni, R. Oggero, and L. Silvestro, "Ghrelin, leptin and IGF-I levels in breastfed and formula-fed infants in the first years of life," Acta Pædiatrica, vol. 94, no. 5, pp. 531-537, 2005.

[58] F. Savino, M. F. Fissore, S. A. Liguori, et al., "Serum Ghrelin concentration, fasting time and feeding in infants," The Journal of Pediatric Endocrinology \& Metabolism, vol. 20, no. 9, pp. 1027-1033, 2007.

[59] A. Asakawa, A. Inui, T. Kaga, et al., "Ghrelin is an appetitestimulatory signal from stomach with structural resemblance to motilin," Gastroenterology, vol. 120, no. 2, pp. 337-345, 2001.

[60] D. E. Cummings, "Ghrelin and the short- and long-term regulation of appetite and body weight," Physiology and Behavior, vol. 89, no. 1, pp. 71-84, 2006.

[61] M. Tschop, D. L. Smiley, and M. L. Heiman, "Ghrelin induces adiposity in rodents," Nature, vol. 407, no. 6806, pp. 908-913, 2000.
[62] J. V. Zhang, P.-G. Ren, O. Avsian-Kretchmer, et al., "Obestatin, a peptide encoded by the ghrelin gene, opposes ghrelin's effects on food intake," Science, vol. 310, no. 5750, pp. 996-999, 2005.

[63] Y. Ozbay, S. Aydin, A. F. Dagli, et al., "Obestatin is present in saliva: alterations in obestatin and ghrelin levels of saliva and serum in ischemic heart disease," BMB Reports, vol. 41, no. 1, pp. 55-61, 2008.

[64] S. Q. Tang, Q. Y. Jiang, Y. L. Zhang, et al., "Obestatin: iots physiochemical characteristics and physiological functions," Peptides, vol. 29, pp. 639-645, 2008.

[65] X.-Y. Dong, J.-M. He, S.-Q. Tang, H.-Y. Li, Q.-Y. Jiang, and X.T. Zou, "Is GPR39 the natural receptor of obestatin?" Peptides, vol. 30, no. 2, pp. 431-438, 2009.

[66] T. Harada, T. Nakahara, D. Yasuhara, et al., "Obestatin, acyl ghrelin, and des-acyl ghrelin responses to an oral glucose tolerance test in the restricting type of Anorexia Nervosa," Biological Psychiatry, vol. 63, no. 2, pp. 245-247, 2008.

[67] A. Juul, "Serum levels of insulin-like growth factor I and its binding proteins in health and disease," Growth Hormone and IGF Research, vol. 13, no. 4, pp. 113-170, 2003.

[68] H. Werner and I. Bruchim, "The insulin-like growth factor-I receptor as an oncogene," Archives of Physiology and Biochemistry, vol. 115, no. 2, pp. 58-71, 2009.

[69] P. D. Gluckman, J. J. Johnson-Barrett, J. D. Butler, B. W. Edgar, and T. R. Gunn, "Studies of insuline-like growth factor I and II by specific radio ligand assays in umbilical cord blood," Clinical Endocrinology, vol. 19, pp. 405-413, 1983.

[70] J. Leger, M. Noel, J. M. Limal, and P. Czernichow, "Growth factors and intrauterine growth retardation. II. Serum growth hormone, insulin-like growth factor (IGF) I, and IGF-binding protein 3 levels in children with intrauterine growth retardation compared with normal control subjects: prospective study from birth to two years of age," Pediatric Research, vol. 40, no. 1, pp. 101-107, 1996.

[71] M. Klagsbrun, "Human milk stimulates DNA synthesis and cellular proliferation in cultured fibroblasts," Proceedings of the National Academy of Sciences of the United States of America, vol. 75, no. 10, pp. 5057-5061, 1978.

[72] M. W. Elmlinger, F. Hochhaus, A. Loui, K. W. Frommer, M. Obladen, and M. B. Ranke, "Insulin-like growth factors and binding proteins in early milk from mothers of preterm and term infants," Hormone Research, vol. 68, no. 3, pp. 124-131, 2007.

[73] F. Savino, G. E. Nanni, S. Maccario, R. Oggero, and G. C. Mussa, "Relationships between IGF-I and weight $\mathrm{Z}$ score, BMI, tricipital skin-fold thickness, type of feeding in healthy infants in the first 5 months of life," Annals of Nutrition and Metabolism, vol. 49, no. 2, pp. 83-87, 2005.

[74] C. L. Ogden, M. D. Carroll, L. R. Curtin, M. A. McDowell, C. J. Tabak, and K. M. Flegal, "Prevalence of overweight and obesity in the United States, 1999-2004," The Journal of the American Medical Association, vol. 295, pp. 1549-1555, 2006.

[75] M. K. Badman and J. S. Flier, "The gut and energy balance: visceral allies in the obesity wars," Science, vol. 307, no. 5717, pp. 1909-1914, 2005.

[76] H. L. Burdette, R. C. Whitaker, W. C. Hall, and S. R. Daniels, "Maternal infant-feeding style and children's adiposity at 5 years of age," Archives of Pediatrics and Adolescent Medicine, vol. 160, no. 5, pp. 513-520, 2006.

[77] K. K. Ong, "Size at birth, postnatal growth and risk of obesity," Hormone Research, vol. 65, supplement 3, pp. 65-69, 2006. 
[78] J. Baird, D. Fisher, P. Lucas, J. Kleijnen, H. Roberts, and C. Law, "Being big or growing fast: systematic review of size and growth in infancy and later obesity," British Medical Journal, vol. 331, no. 7522, pp. 929-931, 2005.

[79] D. J. Barker, C. Osmond, T. J. Forsén, E. Kajantie, and J. G. Eriksson, "Trajectories of growth among children who have coronary events as adults," The New England Journal of Medicine, vol. 353, no. 17, pp. 1802-1809, 2005.

[80] M. S. Kramer, "Do breastfeeding and delayed introduction of solid foods protect against subsequent obesity?" Journal of Pediatrics, vol. 98, pp. 883-887, 1981.

[81] S. Arenz, R. Rückerl, B. Koletzko, and R. von Kries, "Breastfeeding and childhood obesity-a systematic review," International Journal of Obesity, vol. 28, no. 10, pp. 1247-1256, 2004.

[82] C. G. Owen, R. M. Martin, P. H. Whincup, G. D. Smith, and D. G. Cook, "Effect of infant feeding on the risk of obesity across the life course: a quantitative review of published evidence," Pediatrics, vol. 115, no. 5, pp. 1367-1377, 2005.

[83] T. Harder, R. Bergmann, G. Kallischnigg, and A. Plagemann, "Duration of breastfeeding and risk of overweight: a metaanalysis," American Journal of Epidemiology, vol. 162, no. 5, pp. 397-403, 2005.

[84] J. Armstrong and J. J. Reilly, "Breastfeeding and lowering the risk of childhood obesity," The Lancet, vol. 359, no. 9322, pp. 2003-2004, 2002.

[85] A. Singhal and J. Lanigan, "Breastfeeding, early growth and later obesity," Obesity Reviews, vol. 8, supplement 1, pp. 5154, 2007.

[86] E. M. Taveras, K. S. Scanlon, L. Birch, S. L. Rifas-Shiman, J. W. Rich-Edwards, and M. W. Gillman, "Association of breastfeeding with maternal control of infant feeding at age 1 year," Pediatrics, vol. 114, no. 5, pp. e577-e583, 2004.

[87] M. J. Heinig, L. A. Nommsen, J. M. Peerson, B. Lonnerdal, and K. G. Dewey, "Energy and protein intakes of breast-fed and formula-fed infants during the first year of life and their association with growth velocity: the DARLING Study," The American Journal of Clinical Nutrition, vol. 58, no. 2, pp. 152 $161,1993$.

[88] C. Hoppe, C. Molgaard, A. Vaag, V. Barkholt, and K. F. Michaelsen, "High intakes of milk, but not meat, increase sinsulin and insulin resistance in 8-year-old boys," European Journal of Clinical Nutrition, vol. 59, no. 3, pp. 393-398, 2005.

[89] R. W. Taylor, A. M. Grant, A. Goulding, and S. M. Williams, "Early adiposity rebound: review of papers linking this to subsequent obesity in children and adults," Current Opinion in Clinical Nutrition and Metabolic Care, vol. 8, no. 6, pp. 607612, 2005.

[90] B. Koletzko, R. von Kries, R. Closa, et al., "Lower protein in infant formula is associated with lower weight up to age $2 \mathrm{y}$ : a randomized clinical trial," The American Journal of Clinical Nutrition, vol. 89, no. 6, pp. 1836-1845, 2009.

[91] M. Hamosh, "Bioactive factors in human milk," Pediatric Clinics of North America, vol. 48, no. 1, pp. 69-86, 2001.

[92] O. Koldovsky, J. Britton, J. Grimes, and P. Schaudies, "Milkborne epidermal growth factor (EGF) and its processing in developing gastrointestinal tract," Endocrine Regulations, vol. 25, no. 1-2, pp. 58-62, 1991.

[93] N. Shehadeh, R. Shamir, M. Berant, and A. Etzioni, "Insulin in human milk and the prevention of type 1 diabetes," Pediatric Diabetes, vol. 2, no. 4, pp. 175-177, 2001.

[94] C. L. Wagner, S. N. Taylor, and D. Johnson, "Host factors in amniotic fluid and breast milk that contribute to gut maturation," Clinical Reviews in Allergy and Immunology, vol. 34, no. 2, pp. 191-204, 2008.
[95] S. Oguchi, K. Shinohara, Y. Yamashiro, W. Walker, and I. Sanderson, "Growth factors in breast milk and their effect on gastrointestinal development," Acta Pædiatrica, vol. 38, pp. 332-337, 1997.

[96] A. Lucas, D. L. Sarson, A. M. Blackburn, T. E. Adrian, A. Aynsley-Green, and S. R. Bloom, "Breast vs bottle: endocrine resposes are different with formula feeding," The Lancet, vol. 1, no. 8181, pp. 1267-1269, 1980. 